\title{
Assessing Physician Response Rate Using a Mixed-Mode Survey
}

Carolyn R. Ahlers-Schmidt, Ph.D. ${ }^{1}$, Amy Chesser, Ph.D. ${ }^{2}$, Traci Hart, Ph.D. ${ }^{2}$, Jordan Jones, D.O. ${ }^{1}$, Katherine S. Williams, M.Ed. ${ }^{1}$, Robert Wittler, M.D. ${ }^{1}$

University of Kansas School of Medicine-Wichita

${ }^{1}$ Department of Pediatrics

${ }^{2}$ Department of Preventive Medicine and Public Health

\begin{abstract}
Background. It is important to minimize time and cost of physician surveys while still achieving a reasonable response rate. Mixed-mode survey administration appears to improve response rates and decrease bias. A literature review revealed physician response rates to mixedmode surveys averaged about $68 \%$. However, no identified studies used the combination of email, fax, and telephone. The purpose of this study was to evaluate physician response rates based on surveys first administered by e-mail, then fax, then telephone.

Methods. Surveys initially were administered by e-mail to 149 physicians utilizing SurveyMonkey@. Two follow-up reminder e-mails were sent to non-respondents at two-week intervals. Surveys then were faxed to physicians who had not responded. A follow-up fax was sent to non-respondents one week later. Finally, phone interviews were attempted with physicians who had not responded by e-mail or fax; each physician was called at least twice. Results. Of the 149 eligible physicians, 102 completed the survey for a response rate of $68.5 \%$. Of those who responded, 49 (48\%) responded by e-mail, $25(24.5 \%)$ by fax, and $28(27.5 \%)$ by phone. Mode of response did not differ by gender, specialization, or years in practice. In addition, mode of response was not related to the primary study question, physician willingness to use text messaging for immunization reminders.
\end{abstract}

Conclusions. This mix of survey methodologies appeared to be a feasible combination for achieving physician responses and may be more cost effective than other mixed methods. KJM 2010; 3(5):1-6.

\section{Introduction}

Due to demanding schedules, physicians remain a difficult population from whom to obtain reliable and valid findings. Previous attempts to survey this population using only e-mailed surveys ${ }^{1}$ has resulted in low response rates. Using a mixed-mode method for conducting physician surveys may yield higher response rates and reduce the risk of eliminating members of the population who do not use certain technologies regularly. ${ }^{2}$

To identify the most effective combination of methods for physician surveys, a literature review was conducted. PubMed, PsychInfo, and Google Scholar were searched for articles with "survey response rate(s)" in the title and were limited to English articles published in the last 10 years. "Physician" was not included to avoid missing articles regarding specialties, such as "family medicine". The search resulted in 149 articles, 103 unduplicated. Titles and abstracts were evaluated by two independent reviewers and articles describing non-physicians were removed $(n=70)$. Full text was reviewed on the remaining 33 articles and 26 were removed for the following reasons: (1) nonphysician respondents, (2) review article, and (3) single method of delivery. Review of the references of the seven remaining articles $^{3-9}$ revealed four additional ones. ${ }^{10-13}$ These 11 articles reported response rates 
from $32 \%$ to $100 \%$ (see Table 1). Mixed methods, follow-ups, and incentives may have impacted response rates.

The combination of e-mail, fax, and telephone survey methods has not been reported, based on our systematic review. Therefore, the purpose of this study was to evaluate physician response rates based on this multi-method approach.

\section{Methods}

As part of a feasibility study to determine the openness of physicians to using text messages for immunization reminders, a 20-question, IRB-approved survey was conducted with family physicians and pediatricians. Contact information was obtained from the local medical society. Surveys initially were administered by e-mail to 149 physicians utilizing SurveyMonkey॰. Two follow-up emails were sent to non-respondents at twoweek intervals. Surveys then were faxed to non-respondents, with a follow-up fax one week later. Finally, phone interviews were attempted with physicians who had not responded by e-mail or fax; each was called twice (Figure 1).

\section{Results}

Of the 149 eligible physicians, 102 completed the survey for a response rate of $68.5 \%$. Of those who responded, $49(48 \%)$ responded by e-mail, $25(24.5 \%)$ by fax, and $28(27.5 \%)$ by phone interview. The majority were male $(60 / 94 ; 64 \%)$, White, not Hispanic $(78 / 96 ; 81 \%)$, and age ranged from 27-73 $(\mathrm{M}=48 ; \mathrm{SD}=9)$. The majority $(60 / 94 ; 64 \%)$ reported having been in practice 10-29 years, followed by 0-9 years $(15 / 94 ; 16 \%)$ and $30-50$ years $(18 / 94 ; 19 \%)$. Seventy-four percent (70/95) practiced family medicine, $24 \%$ practiced (23/95) pediatrics, and 2\% (2/95) selected "other".
Sixty-seven respondents $(66 \%)$ indicated current use of a fax machine in their practice, while 94\% (96) indicated use of a computer with internet access.

Mode of response did not differ by gender $\quad\left(\chi^{2}(2)=1.384, \quad \mathrm{p}=0.501\right)$, specialization $\left(\chi^{2}(2)=1.089, \mathrm{p}=0.580\right)$, or years in practice $(\mathrm{F}(2,91)=1.756, \quad \mathrm{p}=0.178)$. In addition, mode of response was not related to the primary study question, willingness to use text messaging for immunization reminders $\left(\chi^{2}(4)=4.832, \mathrm{p}=0.305\right)$.

\section{Discussion}

Mailed surveys have long been a useful research method with average physician response rates reported in medical journals around $54 \% .{ }^{14}$ However, mailed surveys can be time consuming and costly, with printing, envelopes, and postage estimated as high as $\$ 11$ per response. ${ }^{15}$ Telephone surveys have shown similar rates and cost per response, ${ }^{10}$ but are more time consuming and require an experienced interviewer. ${ }^{16}$ Current technology allows researchers to utilize a variety of newer methods, such as fax and e-mail, that are lower in cost and time requirements.

Lensing et al. ${ }^{17}$ gave physicians the option of receiving a survey by fax, telephone, or mail. Nearly twice as many physicians requested to be surveyed by fax than other modes, and of those, $87 \%$ responded (with fewer follow-ups). Faxing is more cost-effective than mail since no postage is required and surveys can be sent and returned quickly. The costs of designing and sending a fax survey were estimated as low as $\$ 0.52$ per response. ${ }^{18}$ However, there may be difficulty obtaining fax numbers, loss of anonymity of responders, and possible problems in contact, such as busy signals or inoperable machines. 
Table 1. Physician response rates to surveys using a mixed-mode approach.

\begin{tabular}{|c|c|c|c|c|}
\hline Article & $\begin{array}{c}\mathrm{N} \\
\text { Surveyed }\end{array}$ & Group & Response Rate/Method & $\begin{array}{c}\text { Overall } \\
\text { Rate }\end{array}$ \\
\hline $\begin{array}{l}\text { Armstrong } \\
2000^{3}\end{array}$ & 72 & All & $\begin{array}{l}\text { 73.6\% mail } \\
6.9 \% \text { phone follow-up } \\
19.4 \% \text { face-to-face follow-up }\end{array}$ & $100 \%$ \\
\hline \multirow[t]{2}{*}{$\begin{array}{l}\text { Beebe } \\
2007^{10}\end{array}$} & 245 & Web/mail & $\begin{array}{l}\text { 62.9\% web survey with mail survey } \\
\text { follow-up }\end{array}$ & \multirow[t]{2}{*}{$66.7 \%$} \\
\hline & 244 & Mail/web & $70.5 \%$ mail survey with web follow-up & \\
\hline $\begin{array}{l}\text { Fielding } \\
2005^{4}\end{array}$ & 98 & All & $\begin{array}{l}\text { Unknown initial distribution, fax return } \\
\text { requested; mail follow-up with return } \\
\text { envelope }\end{array}$ & $96 \%$ \\
\hline \multirow{2}{*}{$\begin{array}{l}\text { Grava- } \\
\text { Gubins } \\
2008^{5}\end{array}$} & 35,270 & E-mail group & $29.9 \%$ e-mail & \multirow[t]{2}{*}{$31.6 \%$} \\
\hline & 25,541 & Mail group & $34.1 \%$ mail & \\
\hline \multirow[t]{2}{*}{$\begin{array}{l}\text { Keating } \\
2008^{6}\end{array}$} & 286 & $\$ 20$ incentive & $\begin{array}{l}52.1 \% \text { mail with internet option, phone } \\
\text { follow-up with offer of mail or fax } \\
\text { replacement }\end{array}$ & \multirow[t]{2}{*}{$60 \%$} \\
\hline & 292 & $\$ 50$ incentive & $\begin{array}{l}67.8 \% \text { mail with internet option, phone } \\
\text { follow-up with offer of mail or fax } \\
\text { replacement }\end{array}$ & \\
\hline \multirow[t]{2}{*}{ Leece $2004^{11}$} & 221 & Mail & $58 \%$ mail with mail follow-up & \multirow[t]{2}{*}{$51 \%$} \\
\hline & 221 & E-mail & $\begin{array}{l}\text { 45\% e-mail with e-mail follow-up and } \\
\text { final mail follow-up }\end{array}$ & \\
\hline \multirow{2}{*}{$\begin{array}{l}\text { McLaren } \\
2000^{7}\end{array}$} & 305 & Pre-survey call & $61.6 \%$ phone teaser, mail survey & \multirow[t]{2}{*}{$61.5 \%$} \\
\hline & 316 & $\begin{array}{l}\text { Pre-survey } \\
\text { postcard }\end{array}$ & $61.4 \%$ mail teaser, mail survey & \\
\hline \multirow[t]{3}{*}{$\begin{array}{l}\text { McMahon } \\
2003^{12}\end{array}$} & 150 & Mail & $\begin{array}{l}55 \% \text { mail survey with mail follow-up, } \\
\text { then fax or e-mail follow-up }\end{array}$ & \multirow[t]{3}{*}{$53 \%$} \\
\hline & 150 & Fax & $\begin{array}{l}\text { 57\% fax survey with fax follow-up, } \\
\text { then mail or e-mail follow-up }\end{array}$ & \\
\hline & 150 & E-mail & $\begin{array}{l}\text { 47\% e-mail survey with e-mail follow- } \\
\text { up, then mail or fax follow-up }\end{array}$ & \\
\hline Puleo $2002^{8}$ & 761 & All & $\begin{array}{l}64 \% \text { mail } \\
10 \% \text { with phone or e-mail reminder } \\
17 \% \text { phone follow-up }\end{array}$ & $91 \%$ \\
\hline \multirow[t]{2}{*}{$\begin{array}{l}\text { Raziano } \\
2001^{13}\end{array}$} & 57 & Mail & $\begin{array}{l}\text { 77\% mail survey with mail follow-ups } \\
\text { and final e-mail follow-up }\end{array}$ & \multirow[t]{2}{*}{$65.8 \%$} \\
\hline & 57 & E-mail & $\begin{array}{l}58 \% \text { email survey with e-mail follow- } \\
\text { ups and final mail follow-up }\end{array}$ & \\
\hline \multirow[t]{3}{*}{$\begin{array}{l}\text { Recklitis } \\
2009^{9}\end{array}$} & 136 & $\$ 20$ incentive & $\begin{array}{l}\text { 81.6\% mail with internet option, both } \\
\text { e-mail and mail follow-up }\end{array}$ & \multirow[t]{3}{*}{$73.7 \%$} \\
\hline & 135 & $\begin{array}{l}\text { Flash drive } \\
\text { incentive }\end{array}$ & $\begin{array}{l}\text { 63.0\% mail with internet option, both } \\
\text { e-mail and mail follow-up }\end{array}$ & \\
\hline & 135 & $\begin{array}{l}\$ 20 \text { and flash } \\
\text { drive incentive }\end{array}$ & $\begin{array}{l}\text { 76.3\% mail with internet option, both } \\
\text { e-mail and mail follow-up }\end{array}$ & \\
\hline
\end{tabular}




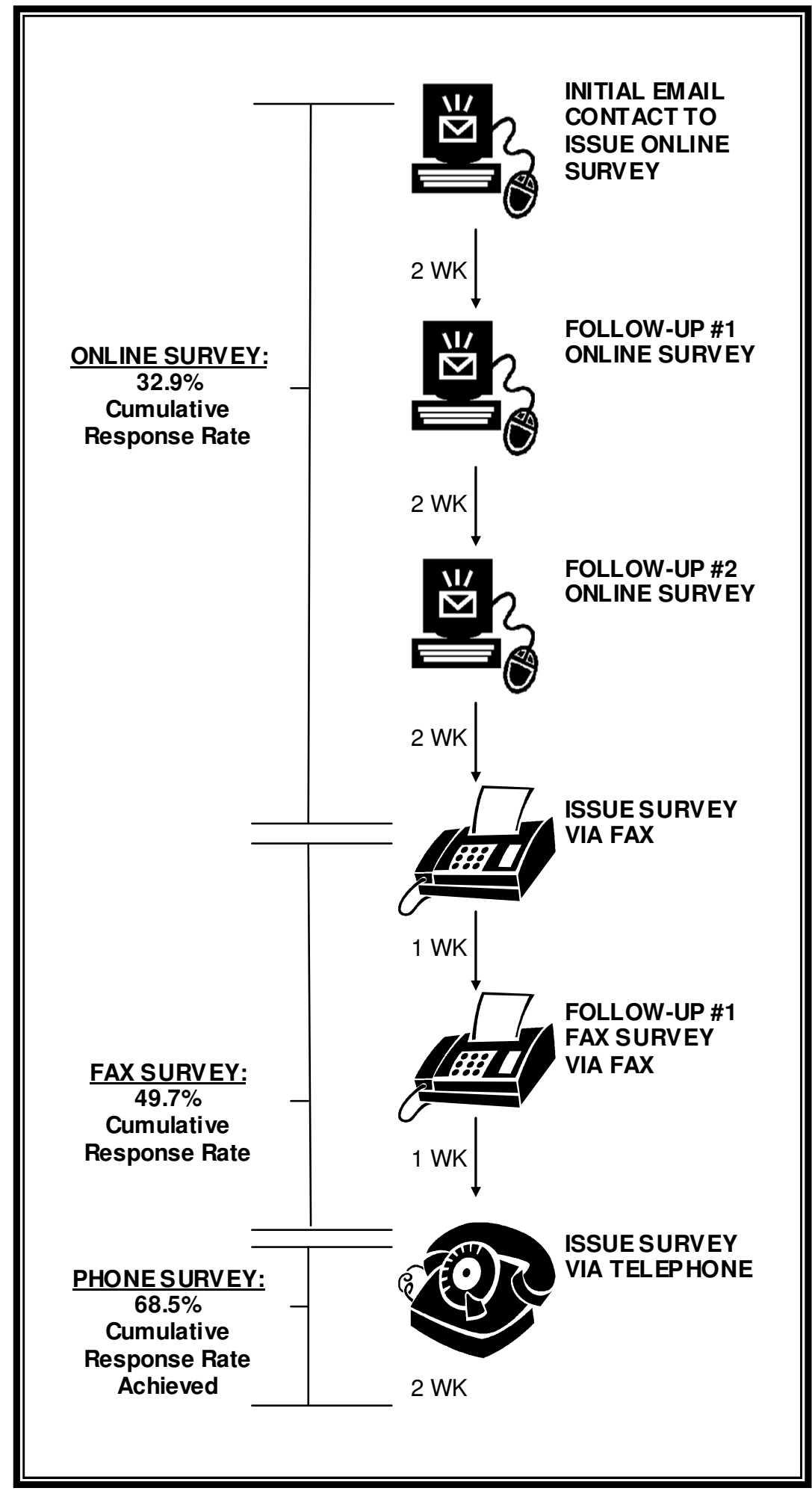

Figure 1. Mixed mode survey response rates and time between follow-ups 
Email surveys can be distributed quickly and inexpensively. Kaplowitz ${ }^{15}$ suggested costs as little as $\$ 1.32$ per response, including computer programming and hosting costs for a web-based survey. Hundreds of surveys can be sent simultaneously by e-mail, while it is often necessary to fax surveys one at a time. Schaefer and Dillman ${ }^{19}$ reported returns came in more quickly by e-mail than mail and answers to open-ended questions were more complete. E-mail has similar limitations to faxing, however, physicians also may neglect to access their e-mail on a regular basis, slowing response time.

Assessing the combination of e-mail, fax, and telephone survey methods, after 10 weeks of data collection, our response rate fell within the average range of multimethod surveys of physicians. Our response rate potentially could have improved if more time were allocated to telephone follow-up. However, our intention was to maximize physician responses in a timely and costeffective manner, and follow-up calls were very time-intensive. We, therefore, opted to discontinue after two attempts per person.

\section{References}

1 Mason BR, Ahlers-Schmidt CR, StuartHilgenfeld M. Adolescent patients: Who is providing their care? Clin Pediatr (Phila) 2010; 49:805-808.

2 Dillman DA, Smyth JD, Christian LM. Internet, Mail, and Mixed-Mode Surveys: The Tailored Design Method. 3rd ed. Hoboken NJ: John Wiley \& Sons, Inc., 2009.

3 Armstrong D, Ashworth M. When questionnaire response rates do matter: A survey of general practitioners and their views of NHS changes. Br J Gen Pract 2000; 50:479-480.

${ }^{4}$ Fielding J, Clothier H, Stocks N, Kelly H. What factors facilitate a GP survey high
Unfortunately, the phone-based studies in Table 1 did not indicate the number of attempts required before physician contact was achieved.

Response rates to phone interviews and fax surveys may have been impacted by clinic staff. Often administrative staff or nurses triage phone calls or fax messages and weed out any that are non-clinical or commercial. Therefore, it is possible some physicians never received the fax or phone message. Other study limitations included: a) the survey was administered in one geographic region; b) no comparison group was used; c) mail and face-to-face interview were not included; d) no incentive was provided, and e) the effects of the questionnaire content, study topic, and question structure were not assessed.

In conclusion, mixed-method survey including e-mail, fax, and telephone followup achieved a reasonable response rate from physicians. Future studies should use randomized groups to assess the cost- and time-effectiveness of different mixed-mode survey techniques.

response rate? Aust Fam Physician 2005; 34:895-896.

${ }^{5}$ Grava-Gubins I, Scott S. Effects of various methodologic strategies: Survey response rates among Canadian physicians and physicians-in-training. Can Fam Physician 2008; 54:1424-1430.

${ }^{6}$ Keating NL, Zaslavsky AM, Goldstein J, West DW, Ayanian JZ. Randomized trial of $\$ 20$ versus $\$ 50$ incentives to increase physician survey response rates. Med Care 2008; 46:878-881.

${ }^{7}$ McLaren B, Shelley J. Response rates of Victorian general practitioners to a mailed survey on miscarriage: Randomised trial of a prize and two forms of introduction to 
the research. Aust N Z J Public Health 2000; 24:360-364.

${ }^{8}$ Puleo E, Zapka J, White MJ, Mouchawar J, Somkin C, Taplin S. Caffeine, cajoling, and other strategies to maximize clinician survey response rates. Eval Health Prof 2002; 25:169-184.

${ }^{9}$ Recklitis CJ, Campbell EG, Kutner JS, Bober SL. Money talks: Non-monetary incentive and internet administration fail to increase response rates to a physician survey. J Clin Epidemiol 2009; 62:224226.

${ }^{10}$ Beebe TJ, Locke GR 3rd, Barnes SA, Davern ME, Anderson KJ. Mixing web and mail methods in a survey of physicians. Health Serv Res 2007; 42(3 Pt 1):1219-1234.

${ }^{11}$ Leece P, Bhandari M, Sprague S, et al. Internet versus mailed questionnaires: $\mathrm{A}$ controlled comparison (2). J Med Internet Res 2004; 6:e39.

${ }^{12}$ McMahon SR, Iwamoto M, Massoudi MS, et al. Comparison of e-mail, fax, and postal surveys of pediatricians. Pediatrics 2003; 111(4 Pt 1):e299-303.

${ }^{13}$ Raziano DB, Jayadevappa R, Valenzula D, Weiner M, Lavizzo-Mourey R. E-mail versus conventional postal mail survey of geriatric chiefs. Gerontologist 2001; 41:799-804.

${ }^{14}$ Asch DA, Jedrziewski MK, Christakis NA. Response rates to mail surveys published in medical journals. J Clin Epidemiol 1997; 50:1129-1136.

${ }^{15}$ Kaplowitz MD, Hadlock TD, Levine R. A comparison of web and mail survey response rates. Public Opin Q 2004; 68:94-101.

${ }^{16}$ Kellerman SE, Herold J. Physician response to surveys. A review of the literature. Am J Prev Med 2001; 20:61-67.

${ }^{17}$ Lensing SY, Gillaspy SR, Simpson PM, Jones SM, James JM. Encouraging physicians to respond to surveys through the use of fax technology. Eval Health Prof 2000; 23:349-360.

${ }^{18}$ Moreo PJ, Warde B, Cobanoglu C. A comparison of mail, fax, and web-based survey methods. International Journal of Market Research 2001; 43:405-410.

${ }^{19}$ Schaefer DR, Dillman DA. Development of a standard e-mail methodology: Results of an experiment. Public Opin Q 1998; 62:378-397.

Keywords: health care surveys, physicians, electronic mail, telefacsimile, Kansas 